\title{
Унификация международного частного права в Европейском союзе*
}

\author{
Юрген Базедов**
}

\section{1. Введение: Кризис конвенций ЕС, содержащих коллизионные нормы}

Авторы Римского договора о ЕЭС (1957 г.)' , провозгласившего создание общего рынка, не уделили особого внимания разработке правового механизма регулирования деловых операций и сделок, совершению которых этот договор был призван способствовать. Он не предусматривал никаких мер в отношении гармонизации или унификации договорного права. Не касался он и проблем международного частного права (далее - МЧП) и лишь призывал в ст. 220 (ныне ст. 293, тире 4) государства-члены в целях обеспечения интересов их граждан «вступать, по мере необходимости, в переговоры по упрощению формальностей, ограничивающих взаимное признание и выполнение решений национальных судов, трибуналов и арбитражей». Как можно судить уже по словам первой фразы («по мере необходимости»), это предписание не заменяет других основных положений Договора, регламентируюших деятельность Сообшества, а скорее дополняет их ${ }^{2}$. Более того, оно как бы указывает на то, что проблема гармонизации или унификации коллизионного права является предметом межправительствен-

\footnotetext{
- Перевод статьи выполнил д.ю.н. Юмашев Юрий Михайлович

•. Юрген Базедов - д.ю.н., профессор, директор Института Макса Планка иностранного и международного частного права.

' Римский Договор от 25.03.1957 г., согласно которому было создано Европейское Экономическое Сообщество (переименованный позднее в Договор о EC), 298 UNTS. 11.

'Cм. также: Schweitzer in Grabitz and Hilf (Eds.). Kommentar zur Europaeischen Union Art.220 EGV No. 2; Schwartz in von der Groeben, Thiesing, Ehlermann (Eds), Kommentar zum EU/EG-Vertrag vol.5, 5th ed. (1997), Art. 220 No.30 et seq. Дело в том, что право, создаваемое на основе ст. 293 посредством заключения международных конвенций между государствами-членами, формально не является правом $\mathrm{EC}$, имеет международно-правовую природу и в литературе государств-членов носит название «сопутствующее право». Трудности, вызываемые таким положением, заставили Сообщество трансформировать, в частности, Брюссельскую конвенцию в Регламент вторичного права ЕС в марте 2002 г. - пер.
} 
ных переговоров государств-членов и не входит в сферу компетенции Сообщества ${ }^{3}$.

Эта точка зрения отражает современное состоянии МЧП в Европейском Союзе. Оно в основном содержится в Брюссельской Конвенции о признании и исполнении судебных решений по гражданским и торговым делам ${ }^{4}$, текст которой был практически дословно воспроизведен в так называемой «параллельной» в Луганской Конвенции об отношениях с «оставшимися странами - участницами Европейской ассоциации свободной торговли $(E A C T)^{5}$, а также в Римской Конвенции о праве, применяемом к договорным обязательствам ${ }^{6}$. С вступлением каждого нового члена в Европейское Сообщество (далее - ЕС) в Брюссельскую и Римскую конвенции должны были вноситься соответствующие изменения, а затем эти конвенции вновь ратифицировались всеми подписавшими их государствами. Увеличение числа государствчленов делало процедуру ратификации все более и более продолжительной ${ }^{7}$, так что Европейская Комиссия была вынуждена предупреждать о возможности применения санкций к тем государствам-членам, которые своевременно не ратифицировали внесенные в конвенции изменения ${ }^{8}$. Традиционный метод унификации МЧП посредством международных конвенций в рамках Сообщества, состоящего из 15 государств-членов, число которых в ближайшем будушем может возрасти до 27 , оказался менее эффективным, чем осуществляемый с помощью регламентов и директив на наднациональном уровне ЕС, поскольку участниками таких конвенций являются государства, и потому в них

\footnotetext{
${ }^{3}$ См. также: von Hoffmann. "The Relevance of European Community Law", in European Private International Law (1998) pp 19-37 (31); de Miguel Asenso. "La evolution del derecho international privato communitario en el Tratado de Amsterdam", 50 Revista Espanola de Derrecho International (1998), 373-376, 3776.

+От 27.09.1968 г. Консолидированная редакция Брюссельской Конвенции после присоединения к ЕС Австрии, Финляндии и Швеции опубликована в О.J. 1998. С 27/1.

${ }^{5}$ OT 24.10.1988. O.J.1988. L $319 / 9$.

${ }^{6}$ От 19.06.1980. Консолидированная редакция после вступления Австрии, Финляндии и Швеции опубликована в О.Ј.1998. С. $27 / 34$.

${ }^{7}$ В июле 1999 г. Европейская Комиссия подвергла критике ситуацию, когда «Брюссельская Конвенция с изменениями, внесенными в связи с присоединением к ЕС Австрии, Финляндии и Швеции, не вступила в силу для всех государств-членов, поскольку лишь меньшинство из них ратифицировало ее».

${ }^{8}$ См. ответ Председателя Комиссии ЕС Монти от 19.11.1996 г. Европейскому Парламенту, О.Ј.,1997. С. 83.35, перепечатанный в Zeitschrift fuer Europaeisches Privatrecht (ZeuP) 1998,368
} 
учитывается в первую очередь национальное законодательство или региональное, если речь идет о федерация ${ }^{9}$. Регламенты же и директивы часто непосредственно регулируют права и обязанности индивидов. И потому международные конвенции по сей день не могут адаптироваться $к$ специфике гармонизированного или унифицированного частного права, вводимого в действие этими актами «вторичного права» Сообщества.

Например, директивы, согласно ст. 249(3) (ех 189) ЕС, действуют в отношении индивидов только после их трансформации в национальный правопорядок, и их нормы уже не являются нормами права Сообщества, а становятся нормами национального права. Таким образом, стороны международных контрактов, имеющих действие на территории Сообщества, могут обходить законы свонх собственных государствчленов, отдав предпочтение праву третьей страны в соответствии co ст. 3 Римской конвенции, даже если в обоих государствах-членах предусмотрен уровень зашиты, рекомендуемый директивой Сообщества. В подобных случаях Сообшество неоднократно было вынуждено для исполнения минимальных стандартов директив прибегать к помощи специальной односторонней коллизионной нормы о «тесной привязке к территории государств-членов», благодаря которой выбранное в качестве статута договора участниками контракта право третьей страны, «негосударства-члена», не порождало правовых последствий.

Часто Сообщество использует также регламенты в качестве инструмента частноправового регулирования ${ }^{10}$. Согласно ст. 249(2) ЕС, регламенты обладают прямым действием и могут распространяться на граждан государств-членов без всяких трансформационных актов. Они имеют приоритет над национальными актами" . Сфера их действия не определяется национальными коллизионными нормам, а устанавливается ими самими. Фактически многие регламенты ЕС расширяют сферу своего действия посредством соответствующих коллизионных норм, которые могут приходить в определенные противоречия с общими принципами международного частного права.

\footnotetext{
'См. так называемые федеральные статьи в различных Гаагских конвенциях, напр., ст.19 The Hague Convention on the law applicable to agency of 14 March 1978 in Hague Conference on private International Law (Ed.), Collection of Conventions 195I-1980, p. 253. см. также ст. 19 Рчмской конвенции.

${ }^{10}$ Первоначальный анализ см.: Basedow "EC Regulations in European Private Law" в Private Law in the International Arena: Festschrift for Kurt Siehr (2000).

"Дело 106/77, Amministrazione delle Finanze dello Statto v. Simmenthal SpA (II). 1978. ECR 629 , paras. $17 / 18$.
} 
Сказанное со всей очевидностью свидетельствует о том, что очень трудно примирить традиционный механизм двусторонних коллизионных норм, установленный, например, Римской конвенцией, и новый механизм одностороннего разграничения сферы применения актов Сообщества. Это требует совершенно нового подхода, связанного с перенесением сферы действия коллизионного права на уровень Сообщества. Изменения, которые Амстердамский договор ${ }^{12}$ внёс в Договор о ЕС, могут привести к коренному пересмотру всей системы коллизионного права на уровне ЕC.

\section{2. Коллизионное законодательство как инструмент политики Сообщества}

В Договоре о Европейском Союзе (Маастрихтский договор) ${ }^{13}$ предпринята первая робкая попытка создать законодательные структуры на европейском уровне, относящиеся к «правосудию и внутренним делам» (Раздел VI Договора), так называемая «третья колонна» Европейского Союза. Среди сфер, представляющих общий интерес и перечисленных в бывшей ст. К 1 (ныне ст. 29 в редакции Амстердамского договора о Европейском Союзе), упоминалось и «правовое сотрудничество по гражданским делам». Значение этого сотрудничества было не совсем ясным и, кроме создания Координационного Комитета и возложения новой обязанности на Совет, Договор не предусматривал никакого нового механизма для достижения этой цели ${ }^{14}$. На раздел VI Договора о сотрудничестве в сфере правосудия и внутренних дел право Сообщества не распространялось. В отношении этой сферы продолжало действовать международное право. Поэтому единственным инструментом законотворчества государств-членов оставались здесь международные конвенции, подлежащие ратификации

12 Договор, изменяющий Договор о Европейском Союзе и Договор о создании Европейского Сообщества. Совершен в Амстердаме 2 октября 1997 г. О.J. 1997, С. 340/1. Русский текст см. «Консолидированная версия Договора о Европейском Союзе и Договора, учреждающего Европейское Сообщество». М.: «Интердиалект». 2001.

1: Договор о Европейском Союзе, совершенный в Маастрихте 7 февраля 1992 г. O.J.1992, C 224/1.

${ }^{14}$ Более подробный анализ см: Mueller-Graff, "The Legal Bases of the Third Pillar and its Position in the Framework of the European Union Treaty", 31 CML Rev.1994, 493-510; Schutte, "Judicial Cooperation under the Union Treaty", in Monar and Morgan (Eds) The Third Pillar of the European Union, 1994, p. 181-191. 
в соответствии с национальными конституционными процедурами. Увы, вновь созданная структура оказалась также незффективной. Единственной конвенцией, касающейся правового сотрудничества в гражданских делах, которая была принята в соответствии со ст. 31 (бывшая ст. К 3), стала так называемая II Брюссельская конвенция о юрисдикции и признании и исполнении судебных решений по брачно-семейным делам ${ }^{15}$, которая так и не вступила в силу из-за недостаточного числа ратификаций государств-членов.

По Амстердамскому договору правовое регулирование сотрудничества по гражданским делам осушествляется уже не Европейским Союзом согласно «третьей колонне» (Раздел VI Договора о Европейском Союзе), а Европейским Сообществом («l колонна», Раздел VI Договора о Европейском Сообществе). Другими словами, Амстердамский Договор перенес регулирование сотрудничества по гражданским делам из сферы действия международного права в сферу действия права EC. Новый раздел IV, озаглавленный «Визы, предоставление убежища, иммиграция и иные вопросы, относяшиеся к свободному передвижению граждан), содержит несколько чрезвычайно сложных положений о будущих действиях Сообщества в этой сфере. Согласно ст. 61(c) Договора о ЕС, Совет должен принимать «меры в сфере правового сотрудничества по гражданским делам в соответствии со ст. $65 \%$ В то же время в уже упоминавшейся ст. 29 (ех К. 1) Договора о Европейском Союзе в настояцей редакции речь идет лишь о «политике и сотрудничестве по уголовным делам». О сотрудничестве по гражданским делам в ней не упоминается. Новая ст. 65 Договора о ЕС поясняет значение «сотрудничества судебных органов по гражданским делам». Согласно ей, «меры в области сотрудничества судебных органов по гражданским делам трансграничного характера, принимаемые согласно ст. 67 постольку, поскольку это необходимо для нормального функционирования внутреннего рынка, должны включать:

а) совершенствование и упрошение:

- системы пересылки из одного государства-члена в другой судебной и внесудебной документации;

- сотрудничества в области сбора свидетельских показаний;

- признания и исполнения решений по гражданским и торговым делам, включая и принятые во внесудебном порядке;

1" C.M. Council Act of 28.05.1998. 
b) стимулирование усилий по сближению коллизионных норм, действующих в государствах-членах, и норм, регулирующих конфликты юрисдикций;

с) устранение препятствий надлежащему исполнению гражданского судопронзводства, и в частности посредством сближения гражданско-процессуальных норм государств-членов, если в этом возникнет необходимость».

\section{3. Правотворчество и роль Суда ЕС}

Ст. 67 Договора о ЕС предусматривает специальную законодательную процедуру, которой должны следовать органы Сообщества в этой области. В первые пять лет правом законодательной инициативы обладают и Сообшество, и государства-члены, а Совет может принимать решения только единогласно, что на практике дает возможность любому государству-члену применить право вето. При этом полномочия Европейского Парламента (ЕП) ограничиваются консультативной функцией. После окончання пятилетнего периода государства-члены теряют право законодательной инициативы, а Совет путем единогласно принятого решения (ст. 67, пункт 2, тире 2) призван заменить законодательную процедуру, предусмотренную в Разделе IV, на процедуру совместного принятия решений, закрепленную в ст. 251. Это в значительной степени усилило бы полномочия ЕП и одновременно привело бы к принятию решений большинством голосов в Совете, лишив тем самым государства-члены права вето.

Возможно, однако, что Совет не сможет прийти к единогласию в этом вопросе, и 5-летний период истечет, а Совет так и не примет решения. Предполагается, что в подобном случае не возникнет никакого правового вакуума. Вместо прежней процедуры уже в силу конечной цели, провозглашенной в ст. 67 (2), будет осуществляться процедура совместного принятия решений Советом и $\mathrm{E} \Pi^{16}$. В пользу такого вывода свидетельствует и следуюшее обстоятельство. Когда Суд провозгласил прямое действие основных экономических свобод (свободы передвижения товаров, услуг, лиц и капиталов) после истечения переходного периода, он поступил так по двум причинам: во-первых,

${ }^{16} Э$ Эа точка зрения разделяется Besse "Die justielle Zusammenarbeit in Zivilrecht nach dem Vertrag von Amsterdam und das EuGVU”, 1999 ZeuP, 107-122 at 100 et seq. 
он понимал, что институты Сообщества обязаны устранить остающиеся ограничения, предусмотренные в первоначальных версиях ст. 52 и 59 (ныне ст. 43 и 49) Договора о ЕС, и, во-вторых, считал, что ситуация, как она изложена в Договоре на момент окончания переходного периода, вполне подходит для прямого действия ${ }^{17}$. Оба условия также выполнены в ст. 67: как было отмечено выше, Совет должен принять единогласное решение после истечения 5-летнего периода, и цель этого решения заключается в том, чтобы применять процедуру совместного принятия решений по крайней мере в одной из сфер, подпадающих под действие Раздела IV. Это находит подтверждение и в Декларациях к Амстердамскому (№ 21) и к Ниццкому (№ 5) договорам, в которых государства-члены подтверждают свое согласие не позднее 01.05.2004 г. решить проблему прямого применения ст. 67 п. 2, тире 2 в соответствии с процедурой совместного принятия решений Советом и ЕП согласно ст. 251 Договора о ЕС.

Принимая во внимание ту поддержку, которую Суд постоянно оказывает ЕП в осуществлении прав последнего, а также его верность демократическим принципам $^{18}$, представляется вполне вероятным, что Суд будет трактовать ст. 67, параграф 2, второе тире, в смысле установления процедуры совместного принятия решений Советом и ЕП в качестве общего принципа. Такая позиция Суда вполне отвечает европейским традициям, которые всегда придавали особое значение демократическому принятию решений в таких областях, как «правосудие и внутренние дела», т.е. в сферах уголовного и гражданского права, оказывающих непосредственное влияние на основные права человека. Включение этих областей в сферу действия права и компетенции Сообщества означает прекращение процедуры ратификации национальными парламентами, а потому усиление прав ЕП представляется необходимой компенсацией в этом отношении.

Другая особенность Раздела IV касается обращения национальных судов государств-членов в Суд ЕС с целью получить предварительное толкование тех или иных положений права ЕС. Ст. 234 Договора о ЕС (ex 177) модифицирована статьей 68 (ex 73p) Договора о ЕС, которая допускает такие обращения только в случаях, когда при рассмотрении

${ }^{7}$ См. о свободе предпринимательства Case 2/74 Reyners v/ Belgium, 1974 REC 631 paras. 24/28.

${ }^{18}$ CM.: Case 138/79 Roquette Freres v. Council, 1980 ECR 333, para 33; Case 139/79 Maizena v. Council, 1980, ECR 3393 para 34; Case C-300-89 Commission v. Council 1991, ECR2867 para 20. 
дела национальным судом в законодательстве данного государствачлена отсутствуют правовые средства, позволяющие оспорить судебное решение заинтересованными лицами. И это положение также может быть изменено по истечении 5 лет Советом согласно ст. 67 (2), тире 2. Тем не менее прямое действие этой нормы в смысле обращения за предварительным толкованием в Суд ЕС по ст. 234 вызывает сомнение, поскольку совершенно неясно, что имеется в виду под формулировкой «приведение в соответствие положений, касающихся полномочий Суда». «Приведение в соответствие» оставлено тем самым на усмотрение политиков. В этой связи ст. 68 не препятствует, по-видимому, Совету также и при принятии отдельных актов предоставлять национальным судам низших инстанций воспользоваться преюдициальной процедурой. Остается лишь надеяться, что Совет воспользуется этой возможностью. Опыт применения ст. 234 показывает, что многие основополагающие решения Суда ЕС были фактически инициированы судами низшей инстанции. И поэтому было бы нецелесообразным ограничивать их право на обрашение в Суд ЕС за предварительным толкованием. Правда, ни Ниццкий Договор, ни первые акты Сообщества в области МЧП не расширили это право. В этой связи заслуживает упоминания, что согласно ст. 68 (3) право обрашаться в Суд ЕС за предварительным толкованием правовых вопросов теперь предоставляется Совету, Комиссии и государствамчленам. Суд ЕС, таким образом, приобретает статус, аналогичный статусу Avocat General по кассационным делам в интересах закона, который существует во французском праве и некоторых других странах романской правовой семьи ${ }^{19}$.

\section{4. Позиция Дании, Ирландии и Соединенного Королевства}

Унификация коллизионных норм в рамках Раздела IV была, к сожалению, непоследовательной и далекой от совершенства ${ }^{20}$. Она была также и неполной, поскольку 3 государства-члена - Дания, Ирландия и Соединенное Королевство - до сих пор так и не участвуют в приня-

${ }^{19} \mathrm{C}$.: Vincent et Guinchard. Procedure civile (23 ed.1994) p. 887; Ferrand, Cassation francaise et Revision allemande, 1993, p.18 seq.

${ }^{20}$ Kohler, "Interrogations sur les sources du droit international prive europeen apres le Traite d Amsterdam", - Revue critique du droit international prive, 1999, 1-30 at 8. 
тии мер по сближению законодательств, предусмотренных в Разделе IV, а посему и не связаны его положениями. Об этом прямо свидетельствует ст. 69 Амстердамского Договора о ЕС, которая отсылает к 2 протоколам, являющимся его неотъемлемой частью. Первый касается позиции Соединенного Королевства и Ирландии, а второй - Дании. Эти три страны опасались потерять контроль над иммиграцией и предоставлением убежиша (гражданам третьих стран) после передачи законодательных полномочий в этой сфере от Союза к Сообществу. Тем не менее. оба протокола содержат лазейки, которые позволят включить эти три государства в процесс унификации коллизионного права в будущем. Ст. 3 Протокола о позиции Соединенного Королевства и Ирландии позволяет каждой из этих стран заявлять об участии в принятии той или иной конкретной меры посредством уведомления Председателя Совета в течение 3 месяцев после внесения в Совет предложения о принятии подобной меры. На заседании Совета, посвяшенном вопросам правосудия и внутренних дел, 12 марта 1999 г. оба государствачлена заявили о своем намерении полностью присоединиться к деятельности Сообшества в области судебного сотрудничества по гражданским делам ${ }^{21}$. Их заявление о подобном намерении в силу ст. 3 равносильно восстановлению для них обязательного действия принимаемых мер.

Ситуация с Данией несколько иная. В сфере судебного сотрудничества по гражданским делам соответствующий протокол не содержит положения, предоставляюшего возможность этой стране участвовать в принятии решений по отдельным конкретным мерам. Но согласно ст. 7 Протокола, Дания может проинформировать другое государствочлен, что она не намерена в дальнейшем следовать:данному Протоколу полностью или частично. В подобном случае она должна применять все соответствующие акты, принятые в рамках Европейского Союза и действующие на данный момент. До настоящего времени Дания не делала подобного заявления в отношении судебного сотрудничества по гражданским делам. Но представляется маловероятным, чтіо опасения Дании в отношении безопасности и суверенитета в области иммиграционных и полицейских вопросов распространяются и на гражданские дела. Что касается институциональных рамок новой компетенции Сообщества, то перспективы в целом на данный момент представляются более оптимистичными, чем может показаться, исходя

${ }^{21} \mathrm{COM}$ (1999) 348 final of 14 july 1999 at 2.2 . 
из критических замечаний в адрес Сообщества об ошибочности избранного им пути 22 .

\section{5. Новая компетенция в системе полномочий Сообщества}

Сообщество активно занималось проблемой коллизионного права в течение многих лет ${ }^{23}$. Большое число директив, особенно в области защиты прав потребителей, содержат коллизионные нормы ${ }^{24}$. Цель этих норм - защитить правовую структуру внутреннего рынка от выбора сторон в пользу закона третьей страны. Они принимались на основании ст. 95 (ех 100а) Договора о ЕС. Сложные всеобъемлющие коллизионные нормы по страховым договорам служат содержанием директив второго и третьего поколений в области страхования, принятых Сообществом на основании ст. 47 (ех 57) и 55 (ех 66) с тем, чтобы обеспечить свободу создания коммерческих предприятий и предоставления услуг на всей территории Сообщества ${ }^{25}$. Основные положения, составляющие суть права международных трудовых договоров, урегулированы согласно соответствующим директивам, также принимаемым на основании ст. 55 (ех 66). Коллизионные нормы есть и в регламентах, принятых в рамках общей транспортной политики согласно ст. 71 (ех 75) или 80 (ex 84) ЕС или на основании дополнительных полномочий Сообщества согласно ст. 308 (ех 235) ЕС.

\footnotetext{
"2 CM.: Schack. "Die EG-Kommission auf dem Holzweg von Amsterdam", 1999 ZeuP, 805-808.

2: Общий обзор см.: Baswedow. Europaeisches Internationales Privatrecht, 1996, NJW, 1921-1929. ${ }^{24}$ С. ., напр., ст. 6 Директивы 93/13 ЕEC.

25 Вторая Директива Совета от 22.06.1988 о координачии законов, регламентов и административных постановлений, касающихся страхования, за исключением страхования жизни, предусматривающая меры по более зффективному претворению в жизнь свободы предоставления услуг и изменяющая Директиву 78/239 ЕС (88/357ЕЭС), О.Ј. 1988, L 172/1; Директива Совета 92/49/ЕЭС от 18.06.1992 о координации законов, регламентов и административных постановлений, касающихся страхования, за исключением страхования жизни, изменяющая Директивы 73/239 ЕС и 88/357Е ЭС (третья Директива по страхованию, за исключением страхования жизни) О.J. 1992, L 228/1; Директива Совета от 08.11.1990 о координации законов, регламентов и административных постановлений, касаюшихся страхования жизни, предусматривающая меры по более эффективному претворению в жизнь свободы предоставления услуг и изменяюшая Директиву 79/267 ЕЭС (90/6 I9ЕЭС), О.J. 1990, L 330/50; Директива Совета 92/96/EЭС от 10.11.1992 о координации законов, правил и административных постановлений, касающихся страхования жизни и изменяющая Директивы 79/267 ЕЭС и 90/619/ЕЭС). (третья Директива по страхованию жизни) О.J. 1992, L 360/1.
} 
После вступления в силу Амстердамского договора наибольший интерес для доктрины МЧП стал представлять наряду с его новым разделом IV и вопрос о соотношении новых компетенций Сообщества и компетенций государств-членов. Меньше внимания уделяется прежней правовой основе Договора о ЕС, опираясь на которую Сообщество могло бы заниматься правотворчеством в области МЧП. Даже создается впечатление, что подобной правовой основы вроде бы и вовсе уже не сушествует. Однако ничто не указывает на то, что новые компетенции, вытекающие из ст. 61 и 65 Договора о ЕС, заменяют или ограничивают прежние. Наоборот, более внимательный анализ приводит к выводу о необходимости «примирить» ст. 61 и 65 с предыдушими компетенциями ${ }^{26}$. В свете вышеприведенных соображений представляется необходимым резюмировать следующее:

- правотворческие процедуры согласно ст. 67 Договора о ЕС отличаются от процедуры ст. 251 в том, что касается права законодательной инициативы, роли ЕП и большинства, требуемого в Совете для принятия решения;

- территориальная сфера действия мер согласно Разделу IV уже, чем сфера действия прочего права ЕС и исключает Данию;

- возможности обрашения в Суд ЕС и как следствие этого развития права ЕС ограничены.

Учитывая сформулированное в ст. 65 Договора о $\mathrm{EC}^{27}$ ограничение в связи с принятием мер, «необходимых для надлежащего функционирования внутреннего рынка», частичное совпадение со ст. 95 ЕС (ех 100а) очевидно. Ведь меры, необходимые для надлежашего функционирования внутреннего рынка, в смысле ст. 65 также должны иметь «в качестве своей цели» установление и функционирование внутреннего рынка, о чем уже идет речь в ст. 95 (1) Договора о ЕС (ex 100а). Таким образом, ст. 95 (1) может служить правовой базой для принятия мер по стимулированию функционирования внутреннего рынка при отсутствии соответствующей компетенции у Сообщества. И для этого не требуется дополнительно использовать ст. 65 в качестве юридической базы. Поэтому Амстердамский договор можно понимать лишь в том смысле, что он установил новую компетенцию Сообщества действовать в коллизионном праве постольку, поскольку ст. 95 не может быть применена в силу её собственного параграфа 2, согласно которо-

\footnotetext{
${ }^{20}$ de Miguel Asenso, op., cit., note 3, 376.

${ }^{27}$ Kohler, op. cit.
} 
му параграф 1 этой статьи не применяется к положениям, регулирующим налогообложение, свободу передвижения лиц и права и интересы наемных работников. А так как положения нового Раздела IV посвящены прежде всего «свободному передвижению индивидов» ${ }^{28}$, ст. 61 и 65 ЕС следует фактически понимать как расширяющие сферу действия общей юридической базы ст. 95 на свободу передвижения лиц ${ }^{29}$. Таким образом, ст. 61 и 65 кажутся вполне подходящей основой для коллизионных норм, регулирующих правовое положение индивидов, включая юридические лица и компании, а также для коллизионных норм в сфере семейных отношений и наследования, если это связано со свободным движением индивидов. В том, что касается коллизионного права Сообшества в отношении контрактов, деликтного права или неосновательного обогащения, это также может оказывать влияние на свободное движение лиц, но обычно оно сильнее сказывается на свободе движения товаров и капиталов. Юридической базой для такого регулирования должна поэтому служить ст. $95^{30}$.

Там, где коллизионное право Сообщества призвано устранить препятствия для свободного движения как лиц, так и товаров и капиталов, там существует потенциальная возможность конфликта между ст. 61,65, с одной стороны, и ст. 95 Договора о ЕС - с другой. В подобных ситуациях Суд ЕС отдавал предпочтение ст. 95, потому что более эффективное участие Европейского Парламента (ЕП), как это предусматривается данной статьей, соответствует основному принципу демократии $^{31}$. Принимая во внимание весьма ограниченные, согласно ст. 67, права ЕП в первые 5 лет переходного периода ${ }^{32}$, можно не сомневаться, что подобные соображения будут преобладать и в данном контексте. Это означает, что насыщенная законодательная программа, которую Комиссия и Совет одобрили в своем совместном плане действий в декабре 1998 г. в целях выполнения нового Раздела IV ${ }^{33}$. должна будет осуществляться в значительной степени на основании ст. 95. Если, например, институты Сообщества попытаются создать новый механизм урегулирования по вопросу о применимом праве к деликт-

\footnotetext{
${ }^{28}$ См. название нового Раздела IV.

29 Эта точка зрения ясно изложена у de Miguel Asenso op.cit. supra note 3, 374

s0 Там же.

${ }^{31}$ Case C-300/89 Commission v. Council ECR/1991 1,2867 para 20.

$\therefore$ См. раздел 2 данной статьи.

:План Действий Совета и Комиссии по наиболее эффективному выполнению положений АД в сфере свободы, безопасности и правосудия. О.J. 1999 С 19/1.
} 
ной ответственности, им предстоит создавать «горизонтальный» механизм, препятствующий распространению ложных сведений и клеветы, нарушениям прав интеллектуальной собственности, свободе конкуренции и т.п. ${ }^{34}$. Надлежащей основой для этого будет служить ст. 95.

Органы ЕС используют в значительной мере возможности, предоставляемые Разделом IV. Принимаемые ими правовые акты до сих пор представляли собой по содержанию трансформированные в регламенты заключенные ранее между государствами-членами международные конвенции. В этой связи можно упомянуть принятые в 2000 г. регламенты о банкротстве, о вручении официальных повесток по трансграничным гражданским и торговым делам, о юрисдикции, признании и исполнении судебных решений по семейным делам, включая ответственность родителей за общих детей (бывшая Брюссельская конвенция 11), о юрисдикции, признании и исполнении судебных решений по гражданским и торговым делам (бывшая Брюссельская конвенция $1)^{35}$. Поскольку непризнание решений о разводе может фактически мешать свободному передвижению супругов, ст. 61 представляется вполне подходящей основой для принятия мер по узаконению этого акта. Совершенно иначе обстоит дело с регламентом Совета о юрисдикции, признании и исполнении судебных решений по гражданским и торговым делам, который предлагает превратить Брюссельскую конвенцию о признании судебных решений в регламент $\mathrm{EC}^{36}$. Этот акт охватывает целый диапазон проблем, относящихся к гражданским и торговым делам, а его влияние на основные свободы не ограничивается свободой индивидов. Поэтому, по мнению автора, его следовало бы основывать на ст. 95, ибо ст. 61 будет явно недостаточно ${ }^{37}$.

Итак, новый Раздел IV расширяет компетенцию Сообшества в коллизионной сфере в меньшей степени, чем может показаться на первый взгляд. Однако он важен в другом отношении - для толкования, в частности, ст. 95. В течение многих лет преобладавшая точка зрения отвергала возможность гармонизации МЧП на основании ст. 95, т.к. считалось, что основные свободы не должны ограничиваться расхождениями в гражданском праве государств-членов, включая МЧП. Ст. 65 делает абсолютно ясным, что этот теоретический аргумент не может

\footnotetext{
${ }^{34}$ План действий см. выше.

${ }^{35} \mathrm{COM}$ (1999) 220 final of 4 may 1999.

${ }^{36} \mathrm{COM}$ (1999) 348 final of 14 july 1999.

`'Вопреки ожиданиям автора его юридической базой послужили ст. 61 (с) и ст. 67 (1). - пер.
} 
больше приниматься во внимание, поскольку, если бы это было верным, то не было бы возможности и для применения этого правового базиса. Но если коллизионные нормы могут влиять на функционирование внутреннего рынка в смысле ст. 65, то нельзя отвергать с порога подобного влияния и в отношении применения ст. 95. Наряду с важностью для коллизионных норм при регулировании личного статуса индивидов, в наследственном, а также в семейном праве, ст. 65 косвенно влияет и на толкование ст. 95 EC, а кроме того, и на ст. 47 и 55 . И именно благодаря толкованию ст. 65 ЕС в будушем коллизионное регулирование может иметь гораздо более широкое применение, чем это имело место до сих пор на основании ст. 95,47 и $55 \mathrm{EC}$.

\section{6. Новые полномочия Сообщества и договоры, заключенные согласно ст. 293 (ех 220)}

Как упоминалось выше, традиционный метод унификации коллизионных норм в ЕС посредством международных конвенций нашел свое отражение в ст. 293 (ех 220) Договора о ЕС. В этой статье четвертое тире гласит: «государства-члены по мере необходимости проводят между собой переговоры с целью обеспечить в интересах своих граждан... упрощение процессуальных формальностей, касающихся взаимного признания и исполнения судебных и арбитражных решений». При разработке проекта Амстердамского договора Комиссия ${ }^{38}$ и Голландия, председательствовавшая в Совете ${ }^{39}$ предложили исключить текст четвертого тире из ст. 293 (ех 220), который стал бы излишним после включения судебного сотрудничества по гражданским делам в сферу действия права Сообщества. Тем не менее текст четвертого тире ст. 293 был сохранен, ибо его содержание не ограничивается гражданскими делами. Норма о взаимном признании и исполнении судебных решений шире, так как включает и уголовное, и налоговое и административное право ${ }^{40}$. Поскольку применение ст. 293, четвертого тире, не исчерпывается лишь передачей правотворческой компетенции, касающейся судебного сотрудничества по гражданским делам, то и исключение данной нормы нельзя считать оправданным.

\footnotetext{
${ }^{38}$ EC Doc. SEC (96) 2004 p. 14

${ }^{39} \mathrm{CM}$. EC Doc. CONF/250096 ADD 1, p. 20

${ }^{+0} \mathrm{CM}$. Basedow, "Europaeische Zivilprozessrecht - Generalia" in Handbuch des Internationalen Zivilverfahrensrechts, vol. I (1982) Kap. II No. 8.
} 
Более того, признание и исполнение судебных решений по ст. 293, четвертое тире, - всего лишь один аспект более широкого сотрудничества по гражданским делам. Об этом можно со всей очевидностью судить по ст. 65 (a), третье тире.

В то же время перечень возможных вопросов, подпадаюших под сферу действия права Сообщества, не является исчерпывающим. Такой вывод можно сделать на основании текста, предшествующего п. (а) ст. 65 Договора о ЕС, в котором подчеркивается, что меры в области судебного сотрудничества по гражданским делам должны «включать» акты, относящиеся к вопросам, перечисленным ниже. Голландия, председательствовавшая в Совете, предложила формулировку («состоит из») $)^{41}$, которую можно было бы толковать как свидетельствующую об исчерпывающем характере данного перечня. Поэтому текст в окончательной редакции не оставляет сомнений в том, что и вне данного перечня сушествуют меры по судебному сотрудничеству в гражданских делах, которые тем не менее могут быть приняты Сообществом согласно ст. 65. Сфера действия данной нормы может показаться, кроме того, ограниченной и на основании критерия, не упомянутого в ст. 293, согласно которому меры, принимаемые по ст. 65, должны быть «необходимы для надлежащего функционирования внутреннего рынка». Но это требование вряд ли создает дополнительные препятствия для правотворческой деятельности. Необходимо иметь в виду, что все меры по гражданским делам согласно Разделу IV относятся к свободному движению лиц ${ }^{42}$, которое в свою очередь является одной из основ внутреннего рынка согласно ст. 14 (ех 7a) Договора о ЕС. Меры, относяшиеся к свободному движению лиц, будут, таким образом, в большинстве случаев необходимы для функционирования внутреннего рынка. Как уже подчеркивалось выше, реальное значение ст. 65 заключается в принципиальном признании того, что правила, регулирующие трансграничное вручение документов, сбор доказательств, юрисдикцию, признание и исполнение судебных решений, коллизии законов и даже аспекты гражданско-процессуального характера, могут оказывать влияние на свободное движение лиц и тем самым на функционирование внутреннего рынка. После того как был признан факт подобного влияния, весьма сложно или даже невозможно провести разграничение между различными типами кол-

\footnotetext{
${ }^{+1}$ См. предложение Голландии по ст.F в документе CONF/2500/96 ADI.

${ }^{22} \mathrm{CM}$. названия Раздела IV Договора о ЕC.
} 
лизионных норм на том основании, например, что признание судебных решений о разводе необходимо для функционирования внутреннего рынка, а признание решений о «законнорожденности» или «незаконнорожденности» детей таковым не является.

Дискуссии по поводу Раздела IV и новых компетенций, которыми Сообщество наделялось в этой связи, не коснулись содержания третьего тире ст. 293 Договора о ЕС. Здесь государствам-членам предлагается провести между собой переговоры и заключить конвенцию о «взаимном признании компаний в смысле ст. 48 (ex 58), сохранении ими своей правосубъектности при переносе ими местонахождения из одного государства-члена в другое и о возможности слияния компаний, созданных в соответствии с правопорядками различных государств-членов».

В основе этой нормы лежит различие критериев, используемых в государствах-членах для определения «национальности» компаний. Если, например, в Голландии и Соединенном Королевстве для этого служит критерий «инкорпорации», то во Франции и Германии критерий «административного центра». Согласно первому критерию, компания при перенесении своей штаб-квартиры в другую страну не теряет своей правосубъектности, а согласно второму - теряет и должна создаваться вновь по законам этой другой страны. И это в значительной степени ограничивает "транснационализацию» бизнеса между государствами-членами.

Уже в 1968 г. государства - члены ЕЭС (тогда их было всего шесть) заключили между собой соответствуюшую конвенцию о взаимном признании компаний согласно третьему тире ст. 220 (ныне ст. 293). Эта конвенция не вступила, однако, в силу, поскольку Нидерланды отказались её ратифицировать. Соответственно она не стала основой для acqueis communautaires, которые новые государства-члены должны были бы принять как часть преимуществ, достигнутых в результате интеграции. Свободное перенесение компаниями своих штаб-квартир из одного государства-члена в другое, что в принципе гарантируется ст. 48 (ех. ст. 58) и что подпадает под понятие свободы движения лиц, остается, таким образом, пока нерешенной проблемой. В 1988 г. Суд ЕС ушел от ответа на этот вопрос, отказавшись в решении по делу Daily Mail or прямого применения ст. 52 (ныне ст. 43). Он высказался в том смысле, что в отсутствие соответствуюших директив Сообщества ст. 52 и 58 Договора о ЕЭС (ныне ст. 43 и 48) не наделяют компа- 
нию, инкорпорированную в одном из государств-членов и имеюшую там свою штаб-квартиру, правом переносить её в другое государствочлен. Это означало, с одной стороны, отсылку к ст. 54 абз. 2 g (ныне ст. 44), которая наделяет Сообщество правом гармонизировать национальное право компаний государств-членов, а с другой - к ст. 220 , третье тире, (ныне ст. 293 ЕС). С тех пор ситуация практически не изменилась, хотя вступил в силу Амстердамский договор (и соответственно его Раздел IV), а Суд ЕС в 1999 г. несколько изменил свою позицию по данному вопросу в решении по делу Centros, высказавшись скореe в пользу критерия «инкорпорации». Какова же в этой связи роль статей 61 и сл.?

В Разделе IV Договора о ЕС в редакции Амстердамского договора свободное движение лиц прямо упоминается уже в заголовке. А в Разделе III речь идет о свободе создания коммерческих предприятий и о свободном движении компаний (ст. $48 \mathrm{EC} \mathrm{-} \mathrm{ex} \mathrm{ст.} \mathrm{58).} \mathrm{Из} \mathrm{сказанно-}$ го можно сделать вывод, что нормы IV Раздела касаются не только физических лиц. Кроме того, ст. 65 (b) прямо наделяет Сообщество компетенцией стимулировать процесс сближения коллизионных норм, действующих в государствах-членах. Всё это во многом говорит за то, что ст. 65 Договора о ЕС позволяет также проводить и гармонизацию права компаний государств-членов. А это, учитывая субсидиарный характер международно-правового механизма статьи 293, ещё более ограничивает возможность межгосударственных переговоров на основе её норм.

\section{7. Трансграничный характер принимаемых мер и отношения с третьими странами}

Еще одна проблема, возникающая в связи с вышеизложенным, - это отношение к третьим странам. Компетентно ли Сообщество принимать коллизионные нормы, регулирующие правоотношения не только внутри Сообшества, но и определяющие юрисдикцию и применимое право в отношении третьих стран? Будет ли оно вправе принимать нормы относительно признания и выполнения решений, принятых судами третьих стран? Ответ совершенно неочевиден ${ }^{43}$. Конечно, желательно, чтобы Сообщество и его государства-члены выступали еди-

${ }^{4} \mathrm{C}$ м. фон Хоффманн ор.cit p. 32. 
ным фронтом в отношении третьих стран ${ }^{44}$.

С другой стороны, упоминания в названии Раздела IV свободы движения лиц и в ст. 65 (и ст. 95) внутреннего рынка, видимо, дают право утверждать, что ст. 65 (и ст. 95) призваны прежде всего регулировать отношения внутри Сообщества. Аналогичный вывод можно сделать, если обратиться и к истории разработки Раздела IV, т.е. ст. «К» Маастрихтского договора о Европейском Союзе. Если согласно ${ }^{45}$ ст. «К. 1 (6)» судебное сотрудничество по гражданским делам представляет обший интерес, то в этом случае трудно понять, почему оно должно включать и сотрудничество между государством-членом и третьими странами. Ограничение сферы сотрудничества рамками Сообщества соответствовало бы коллизионным нормам, принятым для регулирования в сфере страхования, где законы третьих стран не применяются. Можно пойти еше дальше в этом направлении и распространить компетенцию Сообщества на установление общей демаркационной линии в судебной сфере в отношении третьнх стран. Такой подход позволит принять односторонние коллизионные нормы Сообщества, аналогичные тем, которые содержатся во многих директивах по защите прав потребителей. В этих директивах предпринята попытка разграничить сферу действия права Сообщества и сферу действия законов третьих стран.

Но как можно доказать необходимость существования двусторонних коллизионных норм, отсылаюших при определенных обстоятельствах к законам третьих стран, для функционирования внутреннего рынка (ст. 65,95$)$ и свободного движения лиц? Это трудный вопрос, особенно когда речь идет об отношениях государства-члена с третьей страной. Необходимость и оправданность наделения Сообщества соответствующей компетенцией становится более понятной, если речь идет об участии других государств-членов. В данном случае следует исходить из подразумеваемого признания в ст. 65 (b) того, что совместимость коллизионных норм необходима для должного функционирования внутреннего рынка. Применение одного и того же внутреннего закона к одной и той же сделке или случаю судами различных стран, что и является конечной целью сближения или унификации МЧП, при-

\footnotetext{
${ }^{+}$См. Базедов, op.cit. supra note 56, Nos 166 et seq. В отношении Брюссельской конвенции.

${ }^{45}$ Reichert-Faciledes, "Zur Kodifikation des deutsches internationalen Versicherungsvertragsrecht", 1990, IPRax, I-18 at 9 (C-15): нормы директив о страховании применяется только к контрактам страховых компаний, созданных на территория Сообщества, и покрывают риски, имевшие место также на его территории.
} 
вело бы фактически к укреплению правовой стабильности ${ }^{46}$. Это может привести к единообразию принимаемых решений ${ }^{47}$ и в то же время обеспечить защиту законных ожиданий сторон ${ }^{48}$. И тем самым это будет способствовать эффективному использованию основных свобод, закрепленных в Римском договоре о ЕС, что в свою очередь приведет к улучшению функционирования внутреннего рынка.

Если сказанное выше приемлемо для отношений внутри Сообшества, как в принципе предписывается ст. 65 (b), то это должно быть справедливым и в отношении многосторонних сделок с участием третьих стран и по крайней мере двух государств-членов. В подобных случаях всегда существует риск, что суды государств-членов, участвующих в сделке, будут применять различные внутренние законы, которые не смогут удовлетворить законные ожидания сторон. В то время как меры Сообшества, принимаемые согласно ст. 65 или ст. 95, не могут оказать влияния на коллизионные нормы, применяемые судами третьих стран, последние могут использовать коллизионные нормы государств-членов, что, по крайней мере, уменьшит риск принятия противоречащих друг другу решений внутри Сообщества. Такой эффект, на который рассчитаны ст. 65 и ст. 95 , достигается независимо от того, отсылает ли коллизионная норма Сообщества к праву государства-члена или к праву третьей страны. Итак, можно сказать, что статьи 65 и 95 позволяют принять двусторонние коллизионные нормы, по крайней мере в таких многосторонних делах, где участвуют два или более государств-членов.

Невозможно, однако, отделить такие ситуации от отношений между третьими странами и каким-либо одним государством-членом, поскольку вовлечение второго государства-члена может произойти вследствие событий, которые произошли в результате перемены местонахождения одной из сторон, повлекшей за собой появление нового компетентного суда внутри Сообщества. В силу того что каждый суд применяет коллизионные нормы своей страны, всегда будет существовать риск различных решений, и, соответственно, в подобных случаях всегда будет существовать потребность в гармонизации коллизионных норм на уровне Сообщества. Поэтому можно предположить, что нормы ста-

\footnotetext{
${ }^{46}$ Case C $(-440 / 97$; German version in (2000) Wirtschafts- und Steuerrecht, 31 para 23 et seq. ${ }^{47}$ Это считается основной целью МЧП еше со времен Савиньи.

${ }^{48}$ Более осторожную позицию в этом вопросе занимает Коллинз. Dicey and Morris, The Conflich of Laws, vol. I, 11 th ed., London, 1987, p. 5.
} 
тей 65 и 95 требуют широкого толкования, допускающего принятие Сообществом двусторонних коллизионных норм в том, что касается применения к фактическим составам как внутри Сообщества, так и вне его.

Из практики Суда со всей очевидностью следует, что наличие внутренней законодательной компетенции Сообшества подразумевает соответствующую внешнюю компетенцию для переговоров с третьими странами при условии, что такие переговоры необходимы для достижения целей Сообщества ${ }^{49}$. Из вышесказанного следует, что Сообщество сможет участвовать в качестве договаривающейся стороны в будущих международных конвенциях в этой сфере, и в первую очередь в рамках Гаагской конференции по МЧП. Тем не менее, продолжаются дискуссии вокруг того, в какой мере подразумеваемая внешняя компетенция Сообщества является исключительной и в каком объеме продолжает действовать компетенция государств-членов ${ }^{50}$. Сообществу предоставляется возможность вести подобные переговоры совместно с государствами-членами, имеющими богатый опыт и знания в области МЧП. К аналогичной и более четкой оценке компетенции Сообщества можно прийти и в отношении признания и исполнения решений судов третьих стран. Совершенно очевидно, что различия в национальных законах государств-членов в этой области могут привести к ограничению свободы движения лиц. Если, например, судебное решение калифорнийского суда о разводе немецкой пары действительно в Англии, но недействительно в Германии, то в этом случае ситуация ничем не отличается от непризнания решения английского суда о разводе в Германии. В обоих случаях способность супругов перенести свое местожительство из одного государства в другое может быть серьезно затруднена, особенно в случае возможного последующего брака. Таким образом, можно предположить, что компетенция Сообщества по ст. 65 в той же мере действует и в отношении третьих стран в сфере признания и исполнения судебных решений. Соответственно Сообщество будет также наделено компетенцией вести переговоры о договорах по признанию и исполнению судебных решений по граж-

+9 Case 22/70, ERTA, (1971) ECR 263 para 28; последний раз это было подтверждено в решении Суда 1/94 от 15.11.94, BTO (1994) ECR 5267 para 76.

"CM. Emiliou, "The Death of the Exclusive Competence?" (1996) EL Rev., 294, 308; Scheibeck, Die Aussenkompetenzen der EG im internationalen Zivilluftverkehr (Frankfurt' Main, 1999), p. 262-285. 
данским и торговым делам с третьими странами. Такие двусторонние переговоры могут служить альтернативой разрабатываемому в настоящее время проекту Гаагской конвенции о всеобщем признании иностранных судебных решений, принятие которого становится все более проблематичным ${ }^{51}$.

Итак, оценивать компетенцию Сообщества согласно ст. 65 можно по-разному. Соответственно действия Сообщества в этой области будут зависеть от оценки результатов каждого конкретного случая, поэтому проведенный в данной статье анализ нельзя распространять на все сферы, перечисленные в ст. 65.

\section{8. Коллизионное право и конфликт юрисдикций}

Согласно ст. 65 (b) меры Сообщества должны включать меры по стимулированию сближения коллизионных норм, действующих в государствах-членах, и норм, способствующих избежанию конфликта юрисдикций.

Правильное толкование ст. 65 (b) предполагает проведение различия между минимальными требованиями, предъявляемыми к мерам Сообщества, которые принимаются на основании этой статьи, и максимально приемлемыми требованиями к ее содержанию. Совершенно очевидно, что Сообщество может стимулировать сближение национальных коллизионных норм также и посредством рекомендаций, не носящих обязательного характера для государств-членов в отношении ратификации Гаагской конвенции в данной области ${ }^{52}$. Но это никоим образом не может служить ограничением его действий в данной сфере. Оно может способствовать сближению национальных коллизионных норм до тех пор, пока существует возможность принятия различных судебных решений в различных государствах-членах. Опыт Сообшества в области сбллжения национальных законодательств в соответствии со ст. 94 и 95 (ех 100, 100а) показывает, что даже полная гармонизация не исключает риска принятия противоречащих друг другу решений, поскольку правовые нормы, применяемые в различных государствах-членах, все еще остаются национальными как по форме, так и по содержанию. Даже после полной гармонизации сближение

\footnotetext{
"См. критику у Schack, “Entscheidungszustaendegkeiten in einem weltweiten Gerichtsstands-und Vollstreckungsuebereinkommen". (1998) CeuP, 931-956.

3 Kohler, ibid, p.18; Besse, op.cit. p. 115 .
} 
национальных коллизионных норм государств-членов может осуществляться посредством унификации, которая замещает национальные нормы регулированием на уровне Сообщества, в частности посредством принятия регламентов.

Возможное возражение, что ст. 65 (b) предполагает дальнейшее существование национальных коллизионных норм и юрисдикций, основывается на неправильном толковании её текста. В ней речь идет не о «национальных коллизионных нормах и юрисдикциях», а о «нормах, действующих в государствах-членах», что включает как национальные нормы, так и единообразное регулирование посредством актов Сообщества. Более того, в этой связи не следует забывать, что перечисленные в ст. 65 сферы регулирования не являются исчерпывающими. Поэтому ст. 65 разрешает принятие мер даже в тех сферах, которые в ней не перечислены, если речь идет о судебном сотрудничестве по гражданским делам. Вряд ли это можно отрицать и в отношении мер, направленных также на унификацию МЧП.

\section{9. Формы актов Сообщества}

В то время как Договор о ЕС ограничивает компетенцию Сообщества принятием актов определенного типа, таких как, например, директивы $^{53} \cdot$ ст. 65 не содержит никаких ограничений в этом отношении. Нормы этой статьи позволяют принимать «меры», которые включают по крайней мере 5 типов правовых актов Сообщества, перечисленных в ст. 249 (ех 189) Договора о ЕС. Таким образом, не подлежит сомнению, что Сообщество может не только давать рекомендации или заключения, но также наделено компетенцией принимать обязывающие акты, т.е. решения, директивы или даже регламенты ${ }^{54}$. Среди первых предложений Комиссин, основанных на ст. 65 , речь идет о принятии регламентов, которые подлежат прямому применению. Совершенно очевидно, что регламенты - фактически единственная форма правовых актов Сообщества, которая гарантирует и их прямое действие Раздел IV Договора о ЕС о визах, предоставлении убежища, иммиграционной политике и других её направлениях, связанных со свобод-

\footnotetext{
${ }^{3}$ См. среди прочих ст. 44 (1) и ст. 94 Договора о ЕС.

${ }^{54}$ Besse supra note 26 at 115 ; von Hoffmann, supra note 3 , at p.31; Bardenhewer in Lenz (ed), EG-Vertrag Kommentar, 2nd ed, 1999, art. 68, No.7; Petite, "Le traite d'Amsterdam: ambition et realism", 1997/3, RMUE, 17-52 at 27.
} 
ным передвижением граждан, позволяет принимать регламенты и в смежных правовых сферах без ограничений. Более того, можно утверждать, что регламент, который трансформирует Брюссельскую Конвенцию I в акт вторичного права Сообщества, не влечет за собой изменения норм национальных законодательств. И это делает его вполне приемлемым для государств-членов.

\section{0. Заключение}

Перенесение регулирования судебного сотрудничества по гражданским делам на уровень Сообщества показывает, что новая компетенция Сообщества ограничена сферой свободного передвижения лиц, поскольку явная связь между функционированием внутреннего рынка и коллизионным правом, которую создает ст. 65 , предполагает новое и более широкое толкование ст. 95 . В результате статьи 65 и 95 следует рассматривать во взаимосвязи, поскольку обе направлены на устранение ограничений основных свобод, порождаемых коллизией законов государств-членов. Новое регулирование в значительной степени ограничит сферу действия четвертого тире ст. 293 (ех 220) Договора o EC. В том, что касается некоторых, но далеко не всех областей регулирования, перечисленных в ст. 65 , Сообщество даже может принимать меры, которые позволяют применять коллизионные нормы государств-членов к отношениям с третьими странами. Оно также компетентно вести переговоры с третьими странами о заключении международных договоров по поводу этих отношений. Полномочия Сообщества по ст. 65 , равно как и по ст. 95 , позволяют принимать правовые акты всех видов, включая регламенты. В то же время его компетенция не ограничена сферами регулирования, перечисленными в ст. 65 (a-c), в тех случаях, когда действия Сообщества касаются области судебного сотрудничества по гражданским делам. 